\title{
Synthesis and Mechanical Characterization of Iron Oxide Rich Sulfobelite Cements Prepared Using Bauxite Residue
}

\author{
Gustavo Mattos Fortes ${ }^{a}$, Rafaela Roberta Lourenço ${ }^{a}$, Marcelo Montini ${ }^{b}$, Jorge Borges Gallo ${ }^{b}$, \\ José de Anchieta Rodrigues ${ }^{a}$ \\ ${ }^{a}$ Grupo de Engenharia de Microestrutura de Materiais - GEMM, Departamento de Engenharia de \\ Materiais - DEMa, Universidade Federal de São Carlos - UFSCar, \\ Rod. Washington Luiz, Km. 235, 13565-905, São Carlos, SP, Brazil. \\ ${ }^{b}$ Alcoa Alumínio S.A., Rodovia Poços-Andradas, km 10, Poços de Caldas, MG, Brazil.
}

Received: March 28, 2015; Revised: December 1, 2015; Accepted: December 15, 2015

\begin{abstract}
The bauxite residue (BR) is the solid waste of largest generation by the aluminum industry, with a generation estimated in 10 million ton/year in Brazil. Its high alkalinity demands elevated costs to store it safely. Due to the high content of $\mathrm{Al}_{2} \mathrm{O}_{3}$ and $\mathrm{Fe}_{2} \mathrm{O}_{3}$ in $\mathrm{BR}$, the present study evaluated its application for the synthesis of iron rich sulfobelite clinkers. Because of its composition, the cement made with this clinker presents environmental (30\% to $62 \%$ reduction of $\mathrm{CO}_{2}$-equivalent emission), economic and even technical advantages over Portland cements. Formulations containing: limestone, gypsum, BR and clay, were fired at $1230^{\circ} \mathrm{C}$ to synthesize the clinkers. Variations in BR and clay content were studied to obtain three formulations, F-15, F-18 and F-21, of different $\mathrm{Al}_{2} \mathrm{O}_{3} / \mathrm{Fe}_{2} \mathrm{O}_{3}$ ratio values. Cements containing more than $10.5 \mathrm{wt}-\%$ of BR achieved mechanical resistance comparable to Portland cements (CP-II-Z32 and CP-V-ARI) for 7 and 28 days of curing age.
\end{abstract}

Keywords: Bauxite residue, Sulfobelite cement, Low-CO emitting cement, Calcium sulfoaluminate cement, Ettringite.

\section{INTRODUCTION}

A growing challenge the global economy is facing is the need to conciliate economic development, which is based on a large scale production, and environmental protection. The most significant portion of environmental impact is still linked to the industrial activities, as much as it is to the extraction of natural resources, the generation of solid residues and its inadequate destination, and the emission of greenhouse gases and other toxic ones. To solve such an impasse, actions aiming sustainability have been investigated, proposing higher responsibility to economy, environment and society.

The bauxite residue (BR), or red mud, from the Bayer process, is the solid residue of largest volume generated by the aluminum industry. Hence, each ton of alumina $\left(\mathrm{Al}_{2} \mathrm{O}_{3}\right)$ produced generates from 1 to 2.5 tons of $\mathrm{BR}^{1}$. Upon this fact, and considering that in 2012 alumina's world production was of 96.4 million tons $/$ year $^{2}$, it is possible to estimate that the worldwide generation of BR ranges from 96.4 to 241 million ton/year. In the global scenario, Brazil is the third largest generator of BR, only behind China and Australia ${ }^{2}$. Based on its alumina production 10 million tons/year, it is estimated that Brazil generates from 10 to 25 million tons/year of $\mathrm{BR}^{2}$, which represent $10.4 \%$ of the world's output.

Moreover, the safe allocation of these huge volumes of BR allied to its high alkalinity ( $\mathrm{pH}$ from 10 to 13$)^{3}$, due to residual sodium content, demand high investments. Usually,

*e-mail: gustavmf1@gmail.com the management of BR involves the construction and maintenance of "BR lakes", which are large impermeable deposits projected to store the residue safely. Even though its deposition causes complications due to the utilization of large areas and the risk of environmental contamination, the greatest concern about BR is its continuous increasing output, together with the fact that full and inactive deposits have become a permanent responsibility of the industry that produces it.

Among the possible solutions for the BR problem, the use of it as a raw material to fabricate commercial products stands as an advantageous destination, since it would reduce financial and environmental costs associated with its storage, as well as the consumption of natural resources. John and Ângulo ${ }^{4}$ described the steps one should follow to find good use of any solid residue as: the residue characterization, the choices of use; market, economic and environmental analyses. Therefore, the characteristics of BR - as a fine powder rich in iron, aluminum and silicon oxides, nevertheless with high sodium content - have awaken the interest of some industrial sectors in using it mainly in cements for civil construction ${ }^{5}$. The first reason for that is due to its physical and chemical compatibility, which makes of it an interesting raw material choice. Secondly, because of the capability of the cement market to absorb great quantities of residue, since in 2013 Brazil produced 70.2 million tons of Portland cement ${ }^{6}$. Another motivation is that most of large scale production uses of BR is related to cement production ${ }^{7}$. In India, around 
2.5 million ton/year of BR were consumed by cement plants between 1998 and 1999. In China, approximately 10\% of the generated BR is recycled for metal extraction or used as raw material for bricks production. In Japan, the possibility of using BR together with lime, clay, silica and iron sources was considered as raw materials for the cement production. Pilot tests carried out in 2003 confirmed that cements made using BR, as well as mortars and concrete, attended to the Japanese standards. In Greece, efforts of industrial production of cement, bricks and ceramic tiles using BR are at a pilot stage. In the attempt of accelerating that development, the alumina producer "Aluminium de Grece" signed an agreement with Lafarge to supply 200 thousand tons of dry BR per year ${ }^{7}$. In Jamaica, there is a project of a cement plant of 1.5 million tons/year capacity of Portland cement that will use BR as raw material for the clinker ${ }^{8}$.

Generally speaking, cements for civil construction are chemically composed by the main following oxides, in decreasing order: $\mathrm{CaO}, \mathrm{SiO}_{2}, \mathrm{Al}_{2} \mathrm{O}_{3}, \mathrm{Fe}_{2} \mathrm{O}_{3}, \mathrm{SO}_{3}$. In the specific area of cement terminology, it is very common to use the following symbols for these oxides (these symbols will be used along all this text):

$$
\begin{array}{lll}
\mathrm{CaO}=\mathrm{C} & \mathrm{SiO}_{2}=\mathrm{S} & \mathrm{Al}_{2} \mathrm{O}_{3}=\mathrm{A} \\
\mathrm{Fe}_{2} \mathrm{O}_{3}=\mathrm{F} & \mathrm{H}_{2} \mathrm{O}=\mathrm{H} & \mathrm{SO}_{3}=\mathrm{S}
\end{array}
$$

Bellow it is briefly described the main phases that appears in cement constitution and the corresponding hydration reactions:

Alite (tricalcium silicate, $\mathrm{C}_{3} \mathrm{~S}$ ): It is a solid solution, where the coordination of oxygen ions around the calcium ions is irregular, causing great structural voids, which are responsible for the high reactivity of this phase. In industrial clinkers alite may contain in its structure 3 to $4 \%$ of other cations in substitution. In that case, the $\mathrm{Ca}^{+2}$, substituted by $\mathrm{Na}^{+}, \mathrm{K}^{+}, \mathrm{Mg}^{+2}$ and $\mathrm{Fe}^{+3}$; and $\mathrm{Si}^{+4}$ by $\mathrm{Al}^{+3}, \mathrm{P}^{+5}$ and $\mathrm{S}^{+6}$ 9 . Because of the good reactivity, the major constituent of Portland cement guarantees the strength development in the early ages, from 1 to 28 days of cure ${ }^{10}$. The alite hydration forms hydrates of a wide range of morphology and composition, however usually close to $\mathrm{C}_{3} \mathrm{~S}_{2} \mathrm{H}_{3}$, which is called C-S-H gel, and calcium hydroxide (portlandite, $\mathrm{CH}$ ), as the following reaction ${ }^{11}$ :

$$
2 \mathrm{C}_{3} \mathrm{~S}+6 \mathrm{H} \rightarrow \mathrm{C}_{3} \mathrm{~S}_{2} \mathrm{H}_{3}+3 \mathrm{CH}
$$

Belite (dicalcium silicate, $\mathrm{C}_{2} \mathrm{~S}$ ): It is a solid solution, usually found in the form of $\beta-\mathrm{C}_{2} \mathrm{~S}$ polymorph, which hydrates itself slower because it has less irregularities in its structure than alite. This phase contributes significantly to the strength development in the later ages, after 28 days of curing ${ }^{10}$. In industrial clinkers $\beta-\mathrm{C}_{2} \mathrm{~S}$ may contain from 4 to $6 \%$ of oxides in substitution, such as $\mathrm{Al}_{2} \mathrm{O}_{3}$ and $\mathrm{Fe}_{2} \mathrm{O}_{3}$. Other ions such as $\mathrm{Mg}^{+2}, \mathrm{Na}^{+}, \mathrm{K}^{+}, \mathrm{Ba}^{+2}, \mathrm{Cr}^{+4}, \mathrm{Mn}^{+3}, \mathrm{P}^{+5}$ and $\mathrm{S}^{+6}$ can also enter into $\beta-\mathrm{C}_{2} \mathrm{~S}^{9}$. Belite hydrates itself to form the same hydration products as alite, such as the C-S-H gel and portlandite, as the following reaction ${ }^{11}$ :

$2 \mathrm{C}_{2} \mathrm{~S}+4 \mathrm{H} \rightarrow \mathrm{C}_{3} \mathrm{~S}_{2} \mathrm{H}_{3}+\mathrm{CH}$
It is worth to highlight the stoichiometry of hydration reactions, in which belite produces $82 \%$ of $\mathrm{C}_{3} \mathrm{~S}_{2} \mathrm{H}_{3}$ and $18 \%$ of $\mathrm{CH}$, while alite generates $61 \%$ of $\mathrm{C}_{3} \mathrm{~S}_{2} \mathrm{H}_{3}$ and $39 \%$ of $\mathrm{CH}$. The C-S-H gel contributes positively to the mechanical strength, but portlandite does not. Portlandite is prone to solubilization, leaching and carbonation, these events at a certain degree may lead to loss of mechanical properties in the older ages. Due to portlandite deleterious effect, cements with higher belite content present higher final strength and durability than a conventional Portland cement ${ }^{10}$.

Ferrite (calcium aluminate ferrite, $\mathrm{C}_{2}(\mathrm{~A}, \mathrm{~F})$ ): It is a wide solid solution $\mathrm{Ca}_{2}\left(\mathrm{Fe}_{2-\mathrm{x}} \mathrm{Al}_{\mathrm{x}}\right) \mathrm{O}_{5}$, which tends to have an equal $\mathrm{Al}$ and $\mathrm{Fe}$ molar proportion $(\mathrm{x}=1)$, therefore it is usually presented as $\mathrm{C}_{4} \mathrm{AF}$. Its structure is of a perovskite type, with $\mathrm{Fe}^{+3}$ occupying $75 \%$ of octahedral sites and $\mathrm{Al}^{+3}$ filling $75 \%$ of tetrahedral sites ${ }^{12}$. Its reactivity increases with the lower synthesis temperature, as it incorporates more $\mathrm{Al}_{2} \mathrm{O}_{3}{ }^{10,13}$. In that case, the maximum incorporation is reached by $\mathrm{C}_{6} \mathrm{~A}_{2} \mathrm{~F}$ and the minimum one by $\mathrm{C}_{2} \mathrm{~F}^{14}$. $\mathrm{C}_{4} \mathrm{AF}$ contributes more to mechanical strength at later ages ${ }^{15}$. Besides, it adds to cement good chemical resistance, mainly when against sulfate attack $^{10}$. Its hydration leads to the formation of ettringite $\left(\mathrm{C}_{6} \mathrm{AS}_{3} \mathrm{H}_{32}\right)$, iron hydroxide and, depending on the $\mathrm{CSH}_{2} / \mathrm{C}_{4} \mathrm{AF}$ molar ratio of 3 instead of 4 , a certain amount of portlandite is produced, as the following reactions demonstrate, respectively ${ }^{16,17}$ :

$$
\begin{aligned}
& 3 \mathrm{C}_{4} \mathrm{AF}+12 \mathrm{CSH}_{2}+110 \mathrm{H} \rightarrow 4 \mathrm{C}_{6}\left(A_{0,75}, \mathrm{~F}_{0,25}\right) \mathrm{S}_{3} \mathrm{H}_{32}+2 \mathrm{FH}_{3} \\
& \mathrm{C}_{4} \mathrm{AF}+3 \mathrm{CSH}_{2}+30 \mathrm{H} \rightarrow \mathrm{C}_{6} \mathrm{AS}_{3} \mathrm{H}_{32}+\mathrm{FH}_{3}+\mathrm{CH}
\end{aligned}
$$

Klein's Compound - Ye'elimite (calcium sulfoaluminate $\mathrm{C}_{4} \mathrm{~A}_{3} \mathrm{~S}$ ): It is the phase that characterizes sulfobelite cement, but with a broad range of content depending on its purpose. Its crystalline structure consists of a lattice of $\left(\mathrm{AlO}_{4}\right)^{-5}$ tetrahedrals sharing vertices with $\mathrm{Ca}^{+2}$ and $\mathrm{SO}_{4}^{-2}$ ions located in the existing cavities ${ }^{13}$. Its crystalline structure also accepts noticeable amounts of $\mathrm{Fe}^{+3}$ instead of $\mathrm{Al}^{+3}$, although the difference in ionic radius between $\mathrm{Fe}^{+3}(0.675 \AA)$ and $\mathrm{Al}^{+3}$ $(0.535 \AA)$ is of a significant $26 \%{ }^{18}$. Although the maximum percentage of substitution is unknown, values ranging from 9 and $20 \mathrm{wt}-\%{ }^{13}$, until $21.5 \mathrm{wt}-\%$, if the Fe/Al molar ratio reaches $1.5^{19}$ have been reported. The compound $\mathrm{C}_{4} \mathrm{~A}_{3} \mathrm{~S}$ is fast hydrated when in the presence of $\mathrm{CS}$ and $\mathrm{CH}$, resulting in high mechanical strength development due to the formation of ettringite $\left(\mathrm{C}_{6} \mathrm{AS}_{3} \mathrm{H}_{32}\right)$, as the following reactions:

$$
\mathrm{C}_{4} \mathrm{~A}_{3} \mathrm{~S}+2 \mathrm{CSH}_{2}+34 \mathrm{H} \rightarrow \mathrm{C}_{6} \mathrm{AS}_{3} \mathrm{H}_{32}+2 \mathrm{AH}_{3}
$$

$\mathrm{C}_{4} \mathrm{~A}_{3} \mathrm{~S}+8 \mathrm{CSH}_{2}+6 \mathrm{CH}+74 \mathrm{H} \rightarrow 3 \mathrm{C}_{6} \mathrm{AS}_{3} \mathrm{H}_{32}$

In the absence of anhydrite (CS) or gypsite $\left(\mathrm{CSH}_{2}\right), \mathrm{C}_{4} \mathrm{~A}_{3} \mathrm{~S}$ hydrates forming hydrated calcium monossulfoaluminate $\left(\mathrm{C}_{4} \mathrm{ASH}_{12}\right)$, usually called monossulfate, which does not contribute so much to strength development. The following reaction describes the formation of the monossulfate:

$$
\mathrm{C}_{4} \mathrm{~A}_{3} \mathrm{f}+18 \mathrm{H} \rightarrow \mathrm{C}_{4} \mathrm{ASH}_{12}+2 \mathrm{AH}_{3}
$$

Initially, the hydration of $\mathrm{C}_{4} \mathrm{~A}_{3} \mathrm{~S}$ occurs predominantly as shown in Equation $\mathrm{E}$, but, if the dissolution rate of $\mathrm{CS}$ goes lower than the one of $\mathrm{C}_{4} \mathrm{~A}_{3} \mathrm{~S}$, then the hydration might happen partially via Equation $\mathrm{G}^{13}$. 
Calcium aluminates $\left(\mathrm{C}_{3} \mathrm{~A}\right.$ and $\left.\mathrm{C}_{12} \mathrm{~A}_{7}\right)$ : These are phases that hydrate quickly, being responsible for the initial mechanical strength, or the setting of cement ${ }^{10} \cdot \mathrm{C}_{12} \mathrm{~A}_{7}$ has a hydration kinetic slower than $\mathrm{C}_{3} \mathrm{~A}^{13}$. To slow down the hydration of these phases gypsum is added to cement, because of a theory that says gypsum would dissolve quicker, reducing, consequently, the aluminates solubility ${ }^{11}$.

The hydration products generated by $\mathrm{C}_{3} \mathrm{~A}$ hydration in the presence of gypsite can be ettringite $\left(\mathrm{C}_{6} \mathrm{AS}_{3} \mathrm{H}_{32}\right)$ or monossulfate $\left(\mathrm{C}_{4} \mathrm{ASH}_{18}\right)$, depending on the sulfate/aluminate ratio, as the reactions below:

$$
\begin{aligned}
& {\left[\mathrm{Al}(\mathrm{OH})_{4}\right]^{-}+3\left[\mathrm{SO}_{4}\right]^{-2}+6[\mathrm{Ca}]^{+2}+a q . \rightarrow C_{6} A_{3} \mathrm{H}_{32}} \\
& {\left[\mathrm{Al}(\mathrm{OH})_{4}\right]^{-}+\left[\mathrm{SO}_{4}\right]^{-2}+4[\mathrm{Ca}]^{+2}+a q . \rightarrow C_{4} A \mathrm{AH}_{18}}
\end{aligned}
$$

In that case, the formation of ettringite is enhanced by a high sulfate/aluminate ratio ${ }^{11}$. In spite of not finding in technical literature the hydration of $\mathrm{C}_{12} \mathrm{~A}_{7}$ in the presence of gypsum, it is supposed that the reactions could be similar as the ones for $\mathrm{C}_{3} \mathrm{~A}$.

Calcium sulfates (CS and $\mathrm{CSH}_{2}$ ): $\mathrm{CSH}_{2}$ is added to control set time and the hydration products, as seen on the hydration of other phases ${ }^{11}$. The gypsum addition is between 3 and $5 \mathrm{wt}-\%$ t for Portland cement, but for sulfobelite cements this might vary significantly, depending on the proportion of other phases. Usually, this cement possesses CS from excessive gypsum added to the mix of raw materials with the purpose of converting all $\mathrm{Al}_{2} \mathrm{O}_{3}$ to $\mathrm{C}_{4} \mathrm{~A}_{3} \mathrm{~S}$. Hence, residual $\mathrm{CS}$ in the clinker must be considered in the estimation of the quantity of gypsum to be added for a proper hydration ${ }^{13}$. Aiming to obtain high ettringite formation, Chen and Juenger ${ }^{17}$ suggested an empirical formula that calculates the percentage of gypsum to be added, based on $\mathrm{C}_{4} \mathrm{~A}_{3} \mathrm{~S}$, $\mathrm{C}_{4} \mathrm{AF}$ and $\mathrm{CS}$ content, as follows:

$$
\operatorname{Gypsum}(w t-\%)=\frac{126.45\left(\begin{array}{l}
0.4461\left[C_{4} A_{3} S\right]+ \\
1.1205\left[C_{4} A F\right]-[C S]
\end{array}\right)}{\left\{100+1.2645\left(\begin{array}{l}
0.4461\left[C_{4} A_{3} S\right]+ \\
1.1205\left[C_{4} A F\right]-[C S]
\end{array}\right)\right\}}
$$

In the case of existing residual CS or $\mathrm{CSH}_{2}$ that did not react during the hydration of $\mathrm{C}_{4} \mathrm{~A}_{3} \mathrm{~S}$ and $\mathrm{C}_{4} \mathrm{AF}$, those can still react with hydration products, such as $\mathrm{AH}_{3}$ and $\mathrm{CH}$ to form ettringite at a lower rate, as the following reaction ${ }^{13}$ :

$$
\mathrm{AH}_{3}+3 \mathrm{CSH}_{2}+3 \mathrm{CH}+2 \mathrm{OH} \rightarrow \mathrm{C}_{6} \mathrm{AS}_{3} \mathrm{H}_{32}
$$

Portland cement takes almost over the whole civil construction market, but its production is aggressive to the environment causing high energy costs and it is responsible for 5 to $8 \%$ of all $\mathrm{CO}_{2}$-emission related to human activities ${ }^{20}$. Therefore, alternative cements of lower environmental impact, such as sulfobelite cements, have been developed and this study approached exactly the use of BR to synthesize clinkers of sulfobelite cements. These cements, which have been developed in China in the 1970's, have gained a great deal of attention due to their economic, environmental and technical advantages when compared to Portland cements ${ }^{15,18,21}$ :

- Economically, they reduce the energy costs due to their lower burning temperature, which ranges from $1250^{\circ} \mathrm{C}$ to $1300^{\circ} \mathrm{C}$. Another important point is that the more friable obtained clinker diminishes costs of milling.

- Environmentally, they are considered "greener", or of less environmental impact, than cements containing pozzolanic additions, such as fly ash and granulated blast furnace slags. Mainly, however, because they use less limestone $\left(\mathrm{CaCO}_{3}\right)$ and their lower burning temperature reduces $\mathrm{CO}_{2}$-equivalent emissions from $30 \%$ to $62 \%$ in comparison to the production of Portland clinker. Another beneficial point is the use of greater additions of gypsum $\left(\mathrm{CSH}_{2}\right)$ to the clinker, around 15 to $25 \mathrm{wt}-\%$, reducing the clinker content and all the impacts associated with its production. Furthermore, sulfobelite clinkers allow the use of industrial residues and lower quality natural raw materials because its phases can retain in their structures many cations substituting $\mathrm{Al}^{+3}$, such as $\mathrm{Ti}^{+4}, \mathrm{Cr}^{+3}, \mathrm{Mn}^{+3}, \mathrm{Fe}^{+3}, \mathrm{Si}^{+4}$, among others.

- Technically, these cements present high initial and final strength, fast setting proprieties, low expansibility, good impermeability and high corrosion resistance.

Although these are general benefits attributed to sulfobelite cements, the broad variation in their phase composition provides them with advantageous variations over Portland cement. For instance, sulfobelite cements, which are rich in calcium sulfoaluminate $\left(\mathrm{C}_{4} \mathrm{~A}_{3} \mathrm{~S}\right)$, present the greatest technical and environmental advantages. On the other hand, their synthesis demands raw materials rich in alumina sources, which compromises their economic viability. Their small production volume and use of relatively more expensive raw materials, such as bauxite as their alumina source, are the main factors that make their final price almost the double in relation to Portland cements ${ }^{21}$. Still, in China, that cement, under the name of Calcium Sulfoaluminate cement (CSA), is produced in a scale of 1 million tons $/ y^{2} \mathrm{ear}^{22}$. In the USA and Europe, those cements are also produced in small scale compared to Portland cement ${ }^{23}$, and, although used as a substitute for Portland cement, they are more likely to be used as an addition to Portland cements.

Sulfobelite and Portland cements usually have the proportion between their phases as the range of compositions presented in Table 1.

Table 1 - Range of phases proportions of sulfobelite ${ }^{12}$ and Portland cements (based on ${ }^{10}$ ).

\begin{tabular}{lcccccccccc}
\hline \multirow{2}{*}{ Cement } & \multicolumn{10}{c}{ Phases (wt-\%) } \\
\cline { 2 - 11 } & $\mathbf{C}_{3} \mathbf{S}$ & $\mathbf{C}_{2} \mathbf{S}$ & $\mathbf{C}_{4} \mathbf{A}_{3} \mathbf{S}$ & $\mathbf{C}_{4} \mathbf{A F}$ & $\mathbf{C S}$ & $\mathbf{C S H}_{2}$ & $\mathbf{C}$ & $\mathbf{C}_{3} \mathbf{A}$ & $\mathbf{C A}$ & $\mathbf{C}_{12} \mathbf{A}_{7}$ \\
\hline Sulfobelite & - & $10-60$ & $10-55$ & $0-40$ & $0-25$ & & $0-25$ & - & $0-10$ & $0-10$ \\
Portland & $40-65$ & $12-30$ & - & $8-15$ & - & $3-5$ & $0-2$ & $2-14$ & - & - \\
\hline
\end{tabular}


Other proportions of the constituents that have less $\mathrm{C}_{4} \mathrm{~A}_{3} \mathrm{~S}$ and more $\mathrm{C}_{2} \mathrm{~S}$ and $\mathrm{C}_{4} \mathrm{AF}$ do not present so significant environmental and technical advantages, but allow expressive reduction in cost, enhancing their economic viability. Following this trend some studies have investigated the use of BR as one of the raw material for the synthesis of sulfobelitic clinker ${ }^{5,18,22,23}$. Singh et al., investigated the synthesis of iron rich sulfobelitic cement using: hydrated lime 45-50 wt- $\%$, BR 30-35wt- $\%$, bauxite $15-20 \mathrm{wt}-\%$ and gypsum $7.5-10 \mathrm{wt}-\%$. Burning the raw meal at $1250^{\circ} \mathrm{C}$, the clinker composition achieved was majorly $\mathrm{C}_{4} \mathrm{AF}$ e $\mathrm{C}_{4} \mathrm{~A}_{3} \mathrm{~S}$, which after hydration exhibited mechanical strength comparable to Portland cement ${ }^{18}$. Duvallet et al., investigated the possibility of producing a sulfobelitic cement from: hydrated lime, bauxite, BR, fly ashes and bottom ashes. At a proper proportion between $\mathrm{BR}$ and bauxite in the raw meal, it was synthesized a clinker majorly composed of $\mathrm{C}_{4} \mathrm{~A}_{3} \mathrm{~S}, \mathrm{C}_{4} \mathrm{AF}$ and $\mathrm{C}_{2} \mathrm{~S}$. By adding $30 \mathrm{wt}-\%$ of gypsum to this clinker, the resulting cement reached high early mechanical strength and later strength similar to Portland cement ${ }^{22,23}$. Even industrial trials of Lafarge are already trying to produce a sulfobelitic cement, by the name "Aether"TM", and at least in one of their patent $\mathrm{BR}$ is mentioned as a potential raw material ${ }^{5}$.

Therefore, the present study has the aim to develop sulfobelite cements rich in iron, using BR as a raw material, and comparing their strength development to the one of commercial Portland cements (CP-II-Z32 and CP-V-ARI). Hydration products of the synthesized cements were identified using X-Ray diffraction.

\section{MATERIALS AND METHODS}

\subsection{Raw materials}

The raw materials used for the preparation of clinkers and cements were: calcitic limestone, from Mina Santa Helena; São Simão clay, from Minassolo; commercial gypsum, from Fortaleza; and bauxite residue (BR), from Alcoa Alumínio
S.A., in Poços de Caldas-MG, Brazil. The BR was collected presenting mud consistency, in natura, at the disposal stage of the production. Later, it was passed through a filter-press and, after that, dried completely at $110^{\circ} \mathrm{C}$. All the raw materials were milled until they passed completely through a sieve \#200 mesh (75 $\mu \mathrm{m}$ of opening). The chemical composition of the raw materials is presented in Table 2.

The choice of São Simão clay, relatively poor in $\mathrm{Fe}_{2} \mathrm{O}_{3}$, was made to allow greater additions of $\mathrm{BR}$ in order to evaluate the strongest effect that BR can bring to the properties of the synthesized sulfobelite cement.

\subsection{Complementary Materials}

In order to compare the mechanical strength development of synthesized sulfobelite cements, two Brazilian commercial Portland cements were chosen as points of reference, CP-II-Z32 and CP-V-ARI, both by Votorantim-SP. The first reference is a compound Portland cement that can contain $6-14 \mathrm{wt}-\%$ of pozzolan, and the second one is a finer grounded Portland cement, which is richer in alite to achieve higher initial strength (ARI).

Mechanical tests were performed in mortars and these were prepared using sand that attended the requirements of standard NBR $7214^{24}$. The sand was donated by the Instituto de Pesquisas Tecnológicas de São Paulo (IPT). The final sand was composed of the following four grades of size: $n$. 16, n. 30, n. 50 and n. 100.

\subsection{Synthesis of sulfobelite clinkers}

The raw materials were dosed aiming to obtain, after calcination, clinkers of compositions such as those presented in Table 3. In those formulations, the A/F-ratio (alumina modulus) varied, according to the balance between BR and clay and assumed the three following values: 1.5, 1.8 and 2.1, designated as F-15, F-18 and F-21, respectively. Table 4 shows the composition of those three formulations based on oxides.

Table 2 - Chemical composition (in wt-\%) of the raw materials. Places marked with (-) indicate that the quantities were not evaluated.

\begin{tabular}{ccccr}
\hline $\begin{array}{c}\text { Raw Materials / } \\
\text { Components }\end{array}$ & Limestone & Clay & BR & Gypsum \\
\hline $\mathbf{C a O}$ & 56.0 & 0.2 & 3.0 & 34.0 \\
$\mathbf{S i O}_{2}$ & 0.2 & 54.0 & 21.0 & 3.0 \\
$\mathbf{A l}_{2} \mathbf{O}_{3}$ & - & 28.0 & 24.0 & 0.3 \\
$\mathbf{F e}_{2} \mathbf{O}_{3}$ & - & - & 25.0 & 0.1 \\
$\mathbf{S O}_{3}$ & - & - & 8.2 & 46.0 \\
$\mathbf{N a}_{2} \mathbf{O}$ & 0.1 & 3 & 6.8 & 0.3 \\
Others & 56.6 & 12.8 & 88.0 & 5.7 \\
Total & 43.4 & & 12.0 & 89.4 \\
Loss of Ignition & & & 10.6 \\
\hline
\end{tabular}

Table 3 - Raw materials composition of the formulations.

\begin{tabular}{cccrc}
\hline \multirow{2}{*}{ Formulation } & \multicolumn{4}{c}{ Raw materials (wt-\%) } \\
\cline { 2 - 5 } & Limestone & BR & Clay & Gypsum \\
\hline F-15 & 54.2 & 18.6 & 9.3 & 18.0 \\
F-18 & 54.1 & 15.4 & 12.5 & 18.0 \\
F-21 & 54.1 & 13.1 & 14.8 & 18.0 \\
\hline
\end{tabular}


Table 4 - Chemical composition of the clinkers based on oxides.

\begin{tabular}{crcr}
\hline \multirow{2}{*}{ Oxides } & \multicolumn{3}{c}{ Formulation (wt-\%) } \\
\cline { 2 - 4 } & $\mathbf{F - 1 5}$ & $\mathbf{F - 1 8}$ & $\mathbf{F - 2 1}$ \\
\hline $\mathbf{C a O}$ & 51.7 & 51.6 & 51.5 \\
$\mathbf{S i O} \mathbf{2}_{2}$ & 13.5 & 15.0 & 16.1 \\
$\mathbf{A l}_{\mathbf{2}} \mathbf{O}_{\mathbf{3}}$ & 10.1 & 10.3 & 10.4 \\
$\mathbf{F e}_{\mathbf{2}} \mathbf{O}_{3}$ & 6.8 & 5.7 & 5.0 \\
$\mathbf{S O}_{\mathbf{3}}$ & 11.8 & 11.8 & 11.8 \\
$\mathbf{N a}_{\mathbf{2}} \mathbf{O}$ & 2.2 & 1.9 & 1.6 \\
$\mathbf{K}_{\mathbf{2}} \mathbf{O}$ & 0.6 & 0.5 & 0.4 \\
$\mathbf{O t h e r s}$ & 3.4 & 3.2 & 3.2 \\
Total & 100.0 & 100.0 & 100.0 \\
\hline
\end{tabular}

The mixtures were homogenized for 1 hour in a ball mill, applying a ratio of mixture: balls of 1:2 by weight. The mixtures were put in ZAS (zirconia-alumina-silica) crucible and manually pressed with a pestle. Firstly, the samples were heated under a rate of $5^{\circ} \mathrm{C} / \mathrm{min}$ up to $800^{\circ} \mathrm{C}$. At that temperature, the mixture remained still for 0.5 hour, so that the decarbonation of limestone could be completed. After that, the temperature was risen to $1230^{\circ} \mathrm{C}$, under the same heating rate as before. This maximum temperature was previously chosen, because the Ye'elimite content does not increase in higher temperatures, presented low free $\mathrm{CaO}$, and also for energy saving reason. At that maximum temperature, the treatment duration was of 0.5 hour. A cooling process took place inside the electric furnace under a rate of $10^{\circ} \mathrm{C} / \mathrm{min}$. The obtained clinkers were grounded and milled until the material passed through a \#200 mesh sieve.

\subsection{Phases characterization and quantification}

Small fractions of the clinkers were milled until they passed completely through a \#325 mesh sieve for phase characterization by X-Ray Diffraction (XRD). The measurements were made in a diffractometer of the brand Bruker, model D8 FOCUS. The conditions of analysis were: $\mathrm{Cu} \mathrm{K \alpha}(\lambda=1.5406 \AA)$ radiation, filter of $\mathrm{Ni}$; voltage of $40 \mathrm{kV}$; current of $40 \mathrm{~mA}$; scanning by steps of $0.02^{\circ}(2 \theta)$; counting time of $28 \mathrm{~s}$; angular range from 5 to $75^{\circ}(2 \theta)$. The phase quantification was performed in the software TOPAS, which uses the Rietveld Method.

\subsection{Cement preparation}

A certain quantity of gypsum was added to sulfobelite clinker in order to obtain the final cements. The addition was calculated based on the hydration reaction of the phases $\mathrm{C}_{4} \mathrm{AF}$ (Equation $\mathrm{C}$ ) and $\mathrm{C}_{4} \mathrm{~A}_{3} \mathrm{~S}$ (Equation $\mathrm{E}$ ), for the maximum formation of ettringite and minimum of portlandite. The following equation was proposed in the work herein for gypsum addition:

$w-\%$ of Gypsum $=0.843\left(0.52\left[C_{4} A_{3} S\right]+1.417\left[C_{4} A F\right]-1.265[C S]\right)$

After adding gypsum to the clinkers, they were manually homogenized and the sulfobelite cements were finalized.

\subsection{Mechanical Strength and apparent porosity}

Mortars of trace 1:3 (cement: sand) were prepared with a water/cement ratio of 0.50 in weight for the synthesized cements F-15, F-18 and F-21, and of 0.48, for the commercial cements CP-II-Z32 and CP-V-ARI. The different water/cement ratios were adopted to minimize the differences in consistency of the mortars while mixing. The mortars were mixed by adding distilled water, cement and sand to it. The whole process took around 2 minutes. The filling of the molds was done in 3 layers with the help of vibration and pestle for compaction.

After that, the molds were put into a closed humid and saturated environment, which was kept at $23^{\circ} \mathrm{C}$ for curing. After 24 hours, the samples were de-molded and put again into the curing environment until they completed 7 and 28 days. At the end of those periods, the samples were taken to a stove to dry at $50^{\circ} \mathrm{C}$ for $24 \mathrm{~h}$ before testing.

Mechanical strength of the mortars was measured under uniaxial compressive test, using 5 cylindrical samples $(22.5 \mathrm{~mm}$ of diameter by $45.0 \mathrm{~mm}$ of height), for each composition. The test was performed by a universal mechanical testing machine (Material Test System-MTS, series 810), at a loading rate of $140 \mathrm{~N} / \mathrm{s}$. This test attends the NBR 7215 standard $^{25}$, with the exception of the dimensions of the samples, which had been reduced, but kept the same proportion of $1: 2$, for diameter and height.

Mortar cylindrical samples (20 mm of diameter x $20 \mathrm{~mm}$ of height) were used to obtain the apparent porosity, by immersion in kerosene.

\subsection{Hydration Products}

Cementitious pastes were prepared with a water/cement ratio of 0.5 by weight. The mixture of distilled water with cement was made by using a similar procedure as the one described for mortars. After the curing times of 1, 2, 7, 14, 21,28 and 56 days, the curing process was interrupted by the immersion of the samples in a tri-distilled acetone for 1h. After that, the samples were left for drying in a stove at $50^{\circ} \mathrm{C}$, for 24 hours. Pastes were grounded until all the material passed through a \#325 mesh sieve. The obtained powder was analyzed by XRD to determine phase transformations alongside curing ages.

\section{RESULTS AND DISSCUTIONS}

Figure 1 shows the diffractograms of sulfobelite clinkers F-15, F-18 and F-21. It is noticeable for the three formulations that the phases present in the materials were $\beta-\mathrm{C}_{2} \mathrm{~S}$ (monoclinic), $\mathrm{C}_{4} \mathrm{AF}$ (orthorhombic), $\mathrm{C}_{4} \mathrm{~A}_{3} \mathrm{~S}$ (cubic), $\mathrm{C}_{12} \mathrm{~A}_{7}$ (cubic), $\mathrm{CS}$ (orthorhombic), $\mathrm{C}_{2} \mathrm{~F}$ (orthorhombic) and free $\mathrm{CaO}$ (cubic). For their identification, the diffraction patterns used as a reference were those in the ICDD (The International Centre for Diffraction Data) files of numbers 00-033-0302, 01-072-8039, 00-033-0256, 01-073-6332, 00-037-1496, 01-074-3670 and 01-070-5490, respectively.

When comparing the clinker diffractograms, it is significant the change (Figure 1) in the relative intensity of the main peaks when A/F-ratio increases, namely from $\mathrm{F}-15$ to F-21. On F-15, which is higher in Fe, the diffraction peaks of $\mathrm{C}_{4} \mathrm{AF}$ are of relative higher intensities. However, when the A/F-ratio increases to 1.8 and 2.1, $\mathrm{C}_{4} \mathrm{AF}$ decreases in relative intensity, while noticeable gains in intensities happen for $\beta-\mathrm{C}_{2} \mathrm{~S}$ and $\mathrm{C}_{4} \mathrm{~A}_{3} \mathrm{~S}$.

Table 5 presents the quantitative results of the phases in the obtained clinkers by using the Rietveld Method. 
Table 5 - Quantitative phase analyses of the clinkers F-15, F-18 and F-21 using XRD-Rietveld.

\begin{tabular}{|c|c|c|c|c|c|c|c|c|c|}
\hline \multirow{2}{*}{ Clinker } & \multicolumn{7}{|c|}{ Phases (wt-\%) } & \multicolumn{2}{|c|}{ Refinement Parameters } \\
\hline & $\beta-C_{2} S$ & $\mathrm{C}_{4} \mathrm{AF}$ & $\mathrm{C}_{4} \mathrm{~A}_{3} \mathrm{~S}$ & CS & $\mathbf{C}_{12} \mathbf{A}_{7}$ & $\mathrm{C}_{2} \mathbf{F}$ & C & GOF & Rwp \\
\hline F-15 & 46.75 & 27.70 & 6.32 & 7.32 & 5.73 & 2.19 & 3.98 & 1.45 & 7.33 \\
\hline F-18 & 48.93 & 22.33 & 9.34 & 8.79 & 6.01 & 2.27 & 2.32 & 1.46 & 7.58 \\
\hline F-21 & 54.72 & 17.46 & 12.45 & 8.06 & 4.38 & 1.80 & 1.12 & 1.41 & 7.33 \\
\hline
\end{tabular}

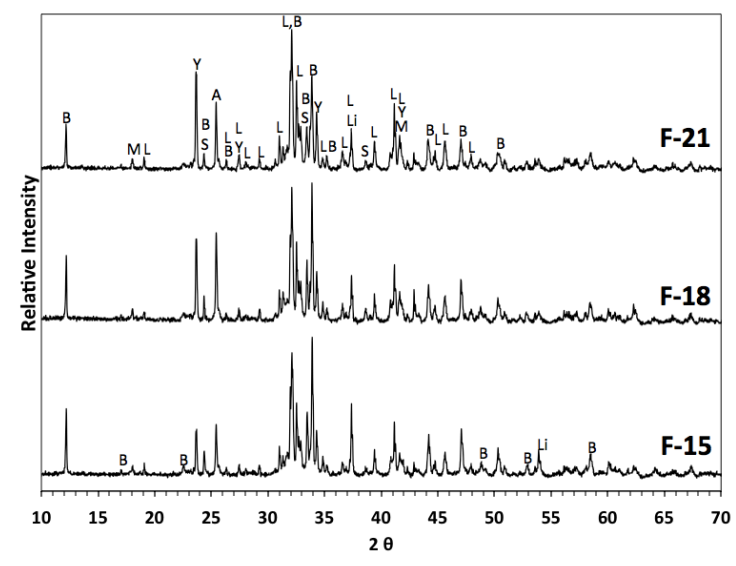

Figure 1 - XRD-patterns of the clinkers F-15, F-18 e F-21. Legend: $\mathrm{L}-\mathrm{\beta}-\mathrm{C}_{2} \mathrm{~S}$ (Larnite); $\mathrm{B}-\mathrm{C}_{4} \mathrm{AF}$ (Brownmillerite); $\mathrm{Y}-\mathrm{C}_{4} \mathrm{~A}_{3} \mathrm{~S}$ (Ye'elimite); $\mathrm{M}-\mathrm{C}_{12} \mathrm{~A}_{7}$ (Mayenite); $\mathrm{A}-\mathrm{CS}$ (Anhydrite); $\mathrm{S}-\mathrm{C}_{2} \mathrm{~F}$ (Srebrodolskite); $\mathrm{Li}-\mathrm{C}$ (Lime).

The respective values and refinement parameters of the Rietveld technique are also presented. GOF-number tends to 1 , when refined, but values below 2 are accepted for quantifications of cements. On the other hand, Rwp-values should be as low as possible. It is noticeable that, for the three formulations F-15, F-18 and F-21, the major phases are $\beta-C_{2} S$ and $C_{4} A F$, and for the last two formulations, $C_{4} A_{3} S$ is the third phase in concentration. Therefore, the increase of 0.6 in $\mathrm{A} / \mathrm{F}$-ratio, from F-15 to F-21, resulted in a rise of $6.1 \mathrm{wt}-\%$ in $\mathrm{C}_{4} \mathrm{~A}_{3} \mathrm{~S}$ in the clinker composition. For instance, it almost doubled its concentration in F-21, in relation to F-15. The modifications in the clinker composition due to the increase of the A/F-ratio were the followings: increase of $8.0 \mathrm{wt}-\%$ of belite ( $17 \%$ relatively); reduction of $10.2 \mathrm{wt}-\%$ of $\mathrm{C}_{4} \mathrm{AF}$ (37\% relatively); and reduction of $2.9 \mathrm{wt}-\%$ of free $\mathrm{CaO}$ ( $72 \%$ relatively). The presence of free lime is a deleterious factor, as much as for mechanical strength, as for the durability of cement, because its hydration generates portlandite $(\mathrm{CH})$, which besides not contributing to strength, it is very susceptible to leaching and chemical attacks. Therefore, cements that would suffer more the negative effect of that constituent would be, in crescent order, F-21, F-18 and F-15.

Figure 2 shows a graph of the phase contents in the clinkers as a function of $\mathrm{A} / \mathrm{F}$-ratio. Regarding that, it is possible to verify the tendency to increase $\mathrm{C}_{4} \mathrm{~A}_{3} \mathrm{~S}$ and $\beta-\mathrm{C}_{2} \mathrm{~S}$, while $C_{4} A F$ is reduced. The explanation for the $\beta-C_{2} S$ increase is that the clay delivers twice the amount of $\mathrm{SiO}_{2}$ than $\mathrm{Al}_{2} \mathrm{O}_{3}$, but that one is used as source of $\mathrm{Al}_{2} \mathrm{O}_{3}$ just to balance A/F-ratio, which inevitably brings an excess of $\mathrm{SiO}_{2}$.

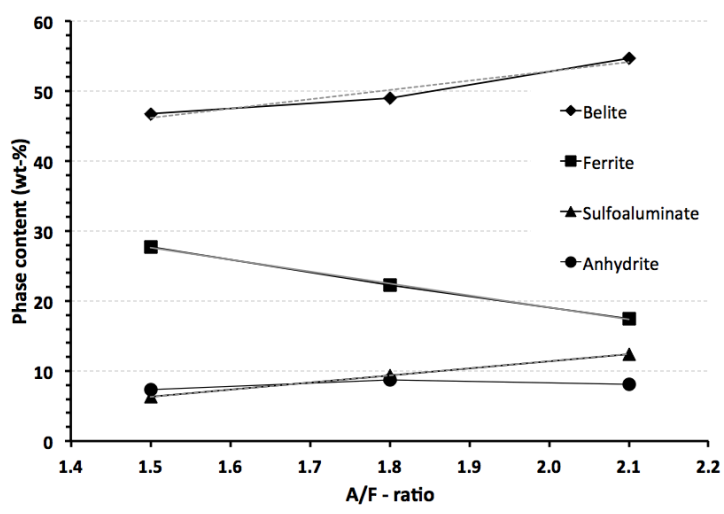

Figure 2 - Percentage of the main phases of the clinkers as a function of $\mathrm{Al}_{2} \mathrm{O}_{3} / \mathrm{Fe}_{2} \mathrm{O}_{3}$-ratio (A/F-ratio).

This demonstrates a limitation of the raw materials used because, to keep increasing A/F-ratio without enhancing an even greater formation of belite, a raw material richer in $\mathrm{Al}_{2} \mathrm{O}_{3}$ should be used, what should be avoided at large scale due to its cost.

Table 5 was taken as a base to determine the proportion of the phases in sulfobelite clinkers and Equation L. Therefore, the gypsum addition needed to prepare each final cement was calculated, aiming maximum ettringite formation as per section 2.5 about cement preparation. The results of this calculation are shown in Table 6. Despite of the addition of gypsum that causes a dilution of BR in the cement, its contend were still higher than $10.5 \mathrm{wt}-\%$ in all formulations.

Results of uniaxial compressive strength of mortars after 7 and 28 days of curing are presented in Figure 3. Initially, when comparing both ages, it is visible that the mechanical performance of F-18 was at least similar to CP-II-Z32, while F-21 reached superior strength, leveling to CP-V-ARI. F-15 did not reach values of strength comparable to the reference cements, but attended the strength required for a class 25 cement $^{9}$.

Concerning the strengths of mortars made of synthesized cement, it is seen that the average values of strength for 7 days presented a linear increase of around $15 \mathrm{MPa}$, as a function of A/F-ratio. However, after 28 days of curing, this tendency was not observed because F-15 had a higher gain of strength, followed by F-18 and F-21. In the case of F-21 almost no gain was observed if the standard deviation is considered.

Analyzing in more details the strength at each curing age; when at 7 days, F-18 and F-21 had superior strengths than CP-II-Z32 and CP-V-ARI, respectively. In contrast, after 28 days, only F-18 remained stronger than CP-II-Z32 
because F-21 did not present an expressive gain, being surpassed by CP-V-ARI.

The mechanical strength development of Portland cements in the curing period of 28 days was mainly controlled by the formation of C-S-H gel, which resulted from $\mathrm{C}_{3} \mathrm{~S}$ hydration. There were also less significant contributions of hydration of $\mathrm{C}_{3} \mathrm{~A}$ and $\mathrm{C}_{4} \mathrm{AF}$ phases that formed calcium monossulfate and ettringite ${ }^{10}$. On the other hand, $\mathrm{C}_{3} \mathrm{~S}$-free sulfobelite cements had their mechanical strength development due to $\mathrm{C}_{4} \mathrm{~A}_{3} \mathrm{~S}, \mathrm{C}_{4} \mathrm{AF}$ and $\mathrm{C}_{12} \mathrm{~A}_{7}$ hydration, which under the adequate presence of $\mathrm{CSH}_{2}$, results in the formation of ettringite. Phases $\mathrm{C}_{12} \mathrm{~A}_{7}$ and $\mathrm{C}_{4} \mathrm{~A}_{3} \mathrm{~S}$ had a quick hydration kinetics and reacted completely in 24 hours, whilst $\mathrm{C}_{4} \mathrm{AF}$ had a slower kinetic than those, but it rose proportionally to the increase of $\mathrm{Al}^{+3}$-containt that substitute $\mathrm{Fe}^{+3}$-ions ${ }^{9,12}$. This was so due to the increasing concentration of $\mathrm{C}_{4} \mathrm{~A}_{3} \mathrm{~S}$ from F-15 (6.32wt- $\left.\%\right)$ to F-21 $\left(12.45 \%\right.$-wt) and the possibility of an $\mathrm{Al}^{+3}$-richer $\mathrm{C}_{4} \mathrm{AF}$ in F-21 than in F-15. The F-21 cement hydrated faster exhibiting higher strength at 7 days. Conversely, F-15 containing $\mathrm{C}_{4} \mathrm{AF}$ of a slower kinetic had a more expressive hydration from 7 to 28 days, almost doubling its strength at that period. The effect of $\beta-\mathrm{C}_{2} \mathrm{~S}$ and $\mathrm{C}_{2} \mathrm{~F}$ had little influence in the early ages, because $\beta-\mathrm{C}_{2} \mathrm{~S}$ only hydrated significantly after 28 days and $\mathrm{C}_{2} \mathrm{~F}$ did not hydrate at all ${ }^{10}$.

Results of apparent porosity at 7 and 28 days are presented in Figure 4. Comparing the results from 7 to the ones of 28 days, a reduction in the apparent porosity was observed because formed hydrates had occupied pores of the mortar.

Comparatively, the apparent porosity of F-18 was similar to the one of CP-II-Z32, for both ages. In the case of F-21 after 7 days of curing, its porosity was similar to the one of CP-V-ARI, but lower than that one after 28 days. Low porosity values, as the one presented by F-21 after 28 days, are beneficial for mechanical strength. That also provides better durability due to the small area of contact and the reduced permeability.

Figure 5 presents a good linear correlation between apparent porosity and mechanical strength. Although that correlation is coherent, other effects must also be considered, for instance, the hydration products and microstructural aspects, such as pore size distribution.

Figure 6 presents anhydrate clinker, F-15, F-18 and F-21, and its cementitious hydrated pastes for increasing the curing time from 1 to 56 days. Besides the typical phases found in the clinker, it was noticed the formation of ettringite (hexagonal), gypsum (monoclinic) and portlandite (hexagonal) in the hydrated pastes. The ICDD file numbers for the hydrated phases are: 01-075-7554 (ettringite), 00-033-0256 (gypsum) and 01-070-5492 (portlandite).

It is observed in Figure 6 diffractograms that, in just 1 day of curing, all cements present a fast ettringite formation (E), that being formed. This should have been a consequence of $\mathrm{C}_{4} \mathrm{~A}_{3} \mathrm{~S}$ hydration, as its main peak is drastically reduced, however it was also the total hydration of $\mathrm{C}_{12} \mathrm{~A}_{7}$ and a small portion of $\mathrm{C}_{4} \mathrm{AF}$. In later ages, the consumption of $\mathrm{C}_{4} \mathrm{AF}$ is observed due to the additional and gradual ettringite formation, but until 56 days of curing all pastes still presented residual $\mathrm{C}_{4} \mathrm{AF}$. An interesting fact concerning F-15 and F-18 pastes is that portlandite peak $(\mathrm{P})$ reaches its maximum intensity at 28 days, but at 56 days that is significantly reduced. In the
Table 6 - Addition of gypsum for each clinker to form the final cements.

\begin{tabular}{cccc}
\hline Formulation & F-15 & F-18 & F-21 \\
\hline wt-\% of gypsum & 28.1 & 21.4 & 17.7 \\
\hline
\end{tabular}

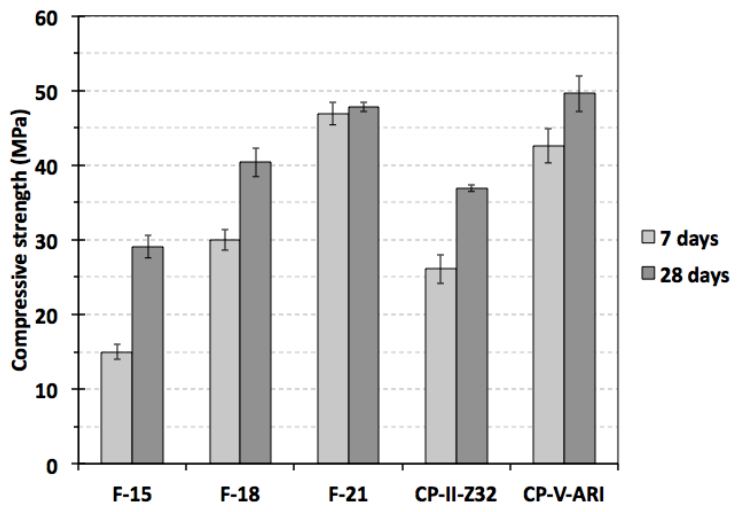

Figure 3 - Compressive strength of mortars prepared using the synthesized and commercial cements. The mortars were cured for 7 and 28 days.

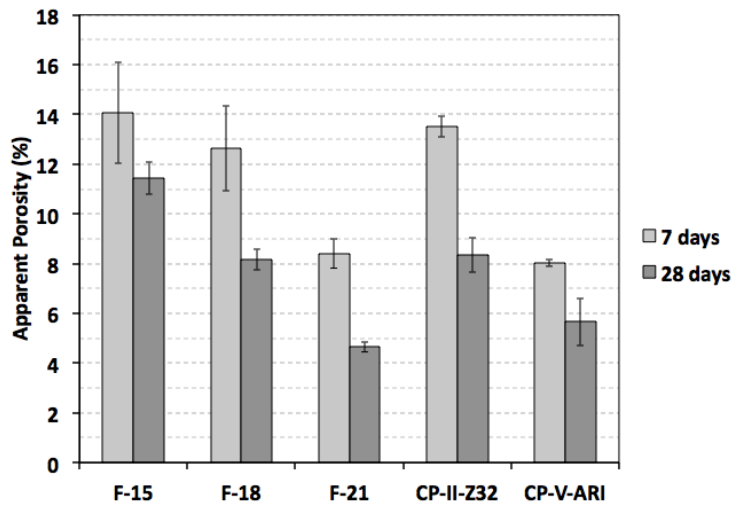

Figure 4 - Apparent porosity of mortars prepared using the synthesized and commercial cements cured for 7 and 28 days.

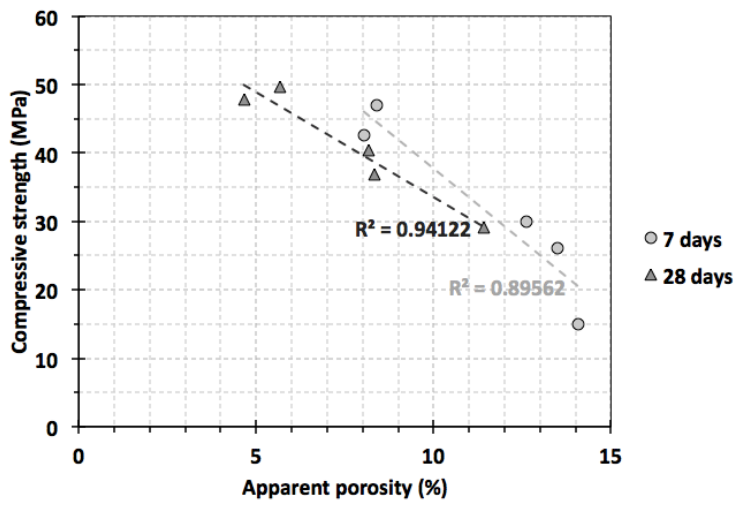

Figure 5 - Correlation between the mechanical strength and the apparent porosity of the prepared mortars using the synthesized and commercial cements. The mortars were cured for 7 and 28 days. 
(a)

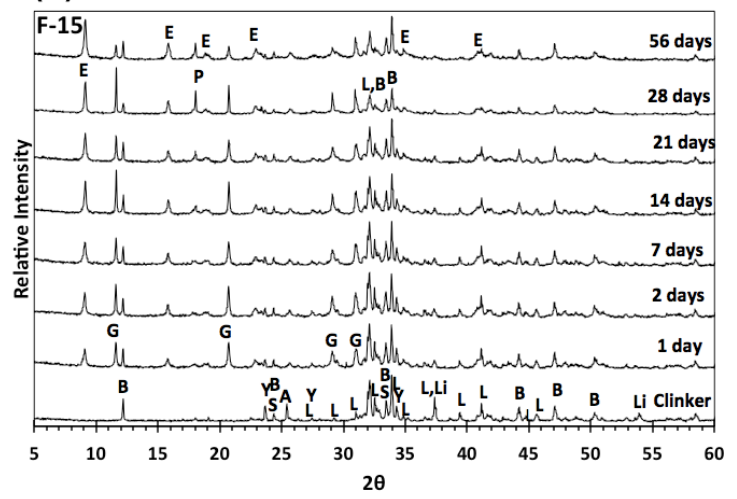

(b)

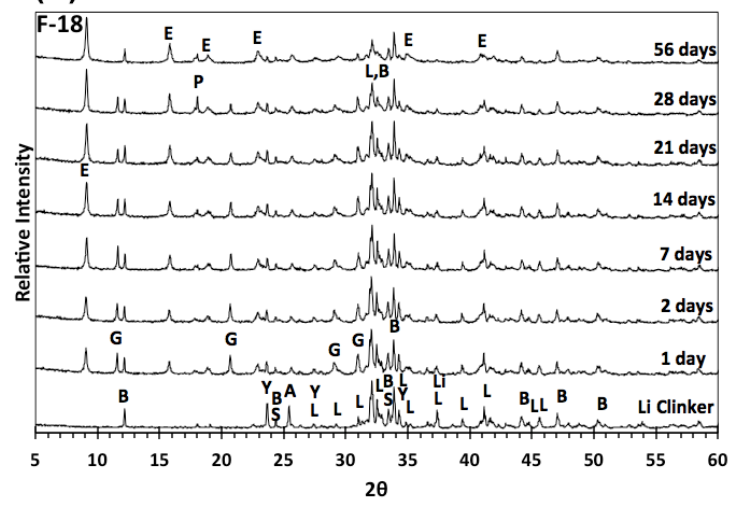

(c)

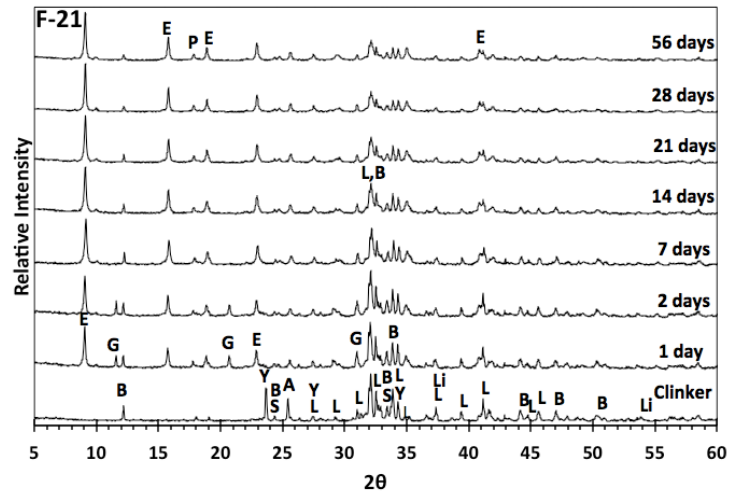

Figure 6 - XRD patterns of (a) F-15, (b) F-18 e (c) F-21 cement pastes cured for different ages, ranging from 1 to 56 days. Legend: $\mathrm{E}-\mathrm{C}_{6} \mathrm{AS}_{3} \mathrm{H}_{32}$ (Ettringite); $\mathrm{L}-\beta-\mathrm{C}_{2} \mathrm{~S}$ (Larnite); $\mathrm{B}-\mathrm{C}_{4} \mathrm{AF}$ (Brownmillerite); $\mathrm{Y}-\mathrm{C}_{4} \mathrm{~A}_{3} \mathrm{~S}$ (Ye'elimite); $\mathrm{G}-\mathrm{CsH}_{2}$ (Gypsum); $\mathrm{M}-\mathrm{C}_{12} \mathrm{~A}_{7}$ (Mayenite); $\mathrm{A}-\mathrm{CS}$ (Anhydrite); $\mathrm{S}-\mathrm{C}_{2} \mathrm{~F}$ (Srebrodolskite); $\mathrm{Li}-\mathrm{C}$ (Lime); P - CH (Portlandite).

case of the gypsum-peak $(\mathrm{G})$, it is also clearly reduced as a function of curing time. This suggests that portlandite, gypsum and aluminum hydroxide, which is not identified in the XRD for not being crystalline, have reacted to form ettringite, as shown in the reaction of Equation $\mathrm{K}$. The amount of hydrated belite $\left(\beta-\mathrm{C}_{2} \mathrm{~S}, \mathrm{~L}\right)$ is not perceptible because its hydration product is the $\mathrm{C}-\mathrm{S}-\mathrm{H}$ gel, which has low degree of order, being hidden in $\mathrm{XRD}^{13}$; and the other hydrate, portlandite, is also delivered by free lime (Li) hydration. Furthermore, the peaks of belite are of low intensity, but, from a slight reduction of intensity and significant portlandite formation, it is possible to state that belite hydrated until 56 days of curing.

It is worth to mention that sulfobelite cements were synthesized by using a reasonable amount of BR, as previously reported $^{18,22,23}$. Cement F-18 made using $10.5 \mathrm{wt}-\%$ of BR, achieved an early high mechanical strength, comparable to what Duvallet et. $\mathrm{al}^{22}$ achieve with a cement made using $10.4 \mathrm{wt}-\%$ of BR. The compressive strength of F-18 was of $30 \mathrm{MPa}$ at 7 days, very close to $29 \mathrm{MPa}$ at 7 days found by Duvallet et. $\mathrm{al}^{22}$. At 28 days, the strength of the cement developed by that researcher reaches $32 \mathrm{MPa}^{22}$, while F-18 reaches $40 \mathrm{MPa}$. Amounts of BR greater than $20 \mathrm{wt}-\%$ on the clinker were not tested, as shown feasible by Singh et. al., ${ }^{15}$ mainly due to concern of a higher $\mathrm{Na}_{2} \mathrm{O}$ content in the Brazilian BR (8.2wt-\%) in comparison to the Indian BR $(5.8 \text { wt- } \%)^{18}$, although $\mathrm{Na}_{2} \mathrm{O}$ on both clinkers reached the similar level around $2 \mathrm{wt}-\%$.

Finally, in comparison to the typical Portland cement, F-18 and F-21 achieved an overall similar mechanical strength and apparent porosity, at the same curing ages due to the rapid ettringite formation and few hydrates of negative contribution, such as portlandite. Broadly, this study brings evidences of the potential of BR use in cements of lower environmental impact. Furthermore, they can have even allowed cost reduction of their processing.

\section{CONCLUSIONS}

The obtained results allowed getting to the following conclusions about the use of bauxite residue (BR) in the preparation of clinkers of sulfobelite cement:

1) XRD qualitative and quantitative analyses showed that it is possible to synthesize clinkers of sulfobelite cement using more than 10.5 wt- $\%$ of BR as raw material. However, formulations with lower BR combined with higher clay amounts have given a higher $\mathrm{Al}_{2} \mathrm{O}_{3} / \mathrm{Fe}_{2} \mathrm{O}_{3}$-ratio of the raw materials mixture, improving the mechanical strength of the obtained cement.

2) Based on the stoichiometry of hydration reactions, an equation for the gypsum addition to the sulfobelite clinker was proposed in the work herein. Its application resulted in cements with a satisfactory mechanical strength development.

3) Sulfobelite cements, F-18 and F-21 achieved mechanical strength and apparent porosity comparable to commercial Portland cements CP-II-Z32 and CP-V-ARI, respectively. High points were that in 7 days of curing mortars F-18 and F-21 attained higher strength than CP-II-Z32 and CP-V-ARI, respectively; and F-21, at 28 days, had an apparent porosity lower than 5\%.

4) Throughout the XRD hydration study of the cementetious pastes cured at certain ages, it was 
verified a rapid ettringite formation after 1 day of curing due to $\mathrm{C}_{4} \mathrm{~A}_{3} \mathrm{~S}$ and $\mathrm{C}_{12} \mathrm{~A}_{7}$ hydration, and the gradual ettringite formation during the 56 days due to $\mathrm{C}_{4} \mathrm{AF}$ hydration. Based on hydration products formed at 28 days, and on the fact that only small amounts of belite hydrate at this age, one can infer that mechanical strengths attained were majorly due to ettringite formation.

\section{REFERENCES}

1. Paramguru RK, Rath PC, Misra VN. Trends in red mud utilization. Mineral Processing \& Extractive Metallurgy Review. 2005;26(1):1-29.

2. Bray EK. 2012 Minerals Yearbook: Bauxite and Alumina. Washington (DC):United States Geological Survey (USGS); 2014. http://minerals.usgs.gov/minerals/pubs/commodity/ bauxite/myb1-2012-bauxi.pdf

3. Silva Filho EB, Alves MC, da Motta M. Lama vermelha da indústria de beneficiamento de alumina: produção, características, disposição e aplicações alternativas. Revista Matéria. 2007;12:322338.

4. John VM, Ângulo CS. Seleção de usos potenciais para os resíduos. Coletânea Habitare. Utilização de resíduos na construção habitacional. 2003;4:64.

5. Pontikes Y, Angelopoulos GN. Bauxite residue in cement and cementitious applications: Current status and a possible way forward. Resources Conservation and Recycling. 2013:73:5363.DOI:10.1016/j.resconrec.2013.01.005

6. Sindicato Nacional da Indústria do Cimento. Relatório Anual 2013. Rio de Janeiro: SNIC; 2013. http://www.snic.org.br/pdf/ RelatorioAnual2013final.pdf

7. Red Mud Project. Industrial Uses. http://redmud.org/utilisation/ industrial-uses/

8. Thame C. Green light for US\$340 million cement plant. Jamaica Observer.Dec 21, 2011. [cited 2015 Mar 21]. Available from: http://www.jamaicaobserver.com/business/Green-light-for-US340-million-cement-plant_10433936

9. Maringolo V. Clínquer co-processado: produto de tecnologia integrada para sustentabilidade e competitividade da indústria de cimento [Tese]. São Paulo; Instituto de Geociências, Universidade de São Paulo (USP); 2001.

10. Kihara Y, Centurione SL. O cimento Portland. In: Isaia GC, editor. Concreto: Ensino, Pesquisa e Realizações. São Paulo: Ibracon; 2005. p. 295-322.

11. Mehta PK. Concreto; estrutura; propriedades e materiais. São Paulo, SP: Pini: 1994.

12. Morsli K, de la Torre AG, Zahir M, Aranda MA. Mineralogical phase analysis of alkali and sulfate bearing belite rich laboratory clinkers. Cement and Concrete Research. 2007;37(5):639-646. doi:10.1016/j.cemconres.2007.01.012

13. Odler I. Special Inorganic Cements. Oxon, England: Taylor \& Francis; 2000. p. 69-84. (Modern Concrete Technology 8).

\section{ACKNOWLEDGMENTS}

Authors are grateful to Alcoa Alumínio S.A., located at Poços de Caldas - MG, for its partnership and co-operation projects (FAI 798-07 and 798-12); to IPT (Instituto de Pesquisas Tecnológicas de São Paulo), for the donation of standard sand; and to CNPq (grants: 138266/2010-7, 303061/2009-0 and 307127/2013-3).

14. Taylor H F W. Cement chemistry. 2nd ed. London, England: Thomas Telford; 1997. p. 13-28.

15. Singh M, Upadhayay SN, Prasad PM. Preparation of special cements from red mud. Waste Management. 1996;16(8):665670. DOI: 10.1016/S0956-053X(97)00004-4

16. Cuberos AJ, de la Torre AG, Alvarez-Pinazo G, Martin-Sedeno MC, Schollbach K, Pollmann H, et al. Active iron-rich belite sulfoaluminate cements: clinkering and hydration. Environment Science Technology. 2010;44(17):6855-6862. doi: 10.1021/ es101785n.

17. Chen IA, Juenger MC. Synthesis and hydration of calcium Sulfoaluminate-belite cements with varied phase compositions. Journal of Materials Science. 2011;46(8):2568-2577.DOI 10.1007/s10853-010-5109-9

18. Singh M, Upadhayay SN, Prasad PM. Preparation of iron rich cements using red mud. Cement and Concrete Research. 1997;27(7):1037-1046.

19. Idrissi M, Diouri A, Damidot D, Greneche JM, Alami Talbi M, Taibi M, Characterization of iron inclusion during the formation of calcium sulfoaluminate phase. Cement and Concrete Research. 2010;40(8):1314-1319. doi:10.1016/j.cemconres.2010.02.009

20. Scrivener KL, Kirkpatrick RJ. Innovation in use and research on cementitious material. Cement and Concrete Research. 2008;38(2):128-136.doi:10.1016/j.cemconres.2007.09.025

21. Jeff Girard's Countertop Solutions. The Pros and Cons of Using CSA Cements. 2008.[cited 2012 Jan 6]. Available from:http:// www.concretenetwork.com/blogs/jeff_girard/2008/12/prosand-cons-of-using-csa-cements.html

22. Duvallet T, Rathbone RF, Henke KR, Jewell RB. Low-energy, low $\mathrm{CO} 2$-emitting cements produced from coal combustion by-products and red mud. In: World of Coal Ash (WOCA). Conference. Lexington, KY, USA. 2009. http://www.flyash. info/2009/044-rathbone2009.pdf

23. Duvallet TY. Influence of ferrite phase in alite-calcium sulfoaluminate cements [Dissertation]. Lexington: College of Engineering, University of Kentucky; 2014. http://uknowledge. uky.edu/cgi/viewcontent.cgi? article $=1027 \&$ context $=$ cme_etds

24. Associação Brasileira de Normas Técnicas. NBR 7214 Areia normal para ensaio de cimento. Rio de Janeiro: ABNT;1982. 7 p.

25. Associação Brasileira de Normas Técnicas. NBR 7215 Cimento Portland-determinação da resistência à compressão. Rio de Janeiro: ABNT;1996. 8 p. 